citly, ESF is saying that it has won the right to be regarded as the natural executive agent of its members for transnational collaboration on a European scale.

The argument is sound, but will it be heeded? Two issues are bound to dominate next week's debate: how promising are the new schemes, and can they be afforded? The underlying objectives are similar - to find ways of giving Europe's scattered academic communities a sense of being part of a critical mass. ESF hopes to be given funds next week to run a two-year pilot programme of conferences, but the case for the potentially more expensive postdoctoral programme is even stronger, if only because there is at present no general means by which people embarking on careers as independent researchers can be helped to move from one European academic centre to another. The underlying objective is to create within some European geographical context a sense that the academic community is a well-integrated whole, untrammelled by national or state boundaries. Until that happens, European science will not make the best of its potential and will remain at a disadvantage with North America.

But there are also difficulties. In breaking this new ground, ESF will, for example, for the first time encounter the too-familiar corrosive internal arguments about 'fair shares' that plague most international organizations: why should members from one country contribute when the immediate beneficiaries may be from elsewhere? The complaint mistakes the objectives, which are communal, not sectional. Specifically, postdoctoral fellows from one country who serve their time in a second and then become full-time academics in a third are only a 'loss' to the first two if the European academic community remains as balkanized as it is at present, which amounts to saying that neither ESF's plans nor other initiatives in the air will have much effect. That is a counsel of despair.

There are also practical difficulties; most postdoctoral fellowships are linked with research grants, for example, especially in the natural sciences. A postdoctoral fellow cannot work effectively without research funds, but universities are at present able to provide for only a few out of their own resources. But it would defeat the purpose of the new schemes if they were confined to fields in which research is relatively cheap, as in the social sciences. Uncertainties such as these, rather than the sheer cost of the postdoctoral scheme (which nevertheless could easily exceed the equivalent of $\$ 30$ million a year) will determine what happens next week. It is to be hoped that ESF's assembly will be ready at least to experiment.

What matters most of all is that ESF's members should have a clear idea of why they are in business at Strasbourg. ESF is by no means the only European institution for the encouragement of transnational science, but it is a distinctive one. It differs from the organs of the European Economic Community (EEC), for example, geographically and by its concern for basic rather than applied science. (The EEC should pay more attention to basic science, but that is another matter.) ESF is also concerned with quality in research, not merely with getting things done. However much it grows, it will not in the foreseeable future be a big spender, but its record shows that its influence can far exceed the scale on which money runs through its hands. The opportunity, now, is to recreate the circumstances of the eighteenth century, when European scholarship was free and also European in the broadest sense manageably so because it was so much smaller. The prize, the reinvigoration of European scholarship - could also be disproportionately handsome.

\section{Strength via adversity?}

Having outlasted an administrative attack, the US fusion programme must not subside into somnolence.

THE only thing worse than a federal science administrator who knows nothing about science is one who does. That, apparently, is the lesson that physicists in the US magnetic fusion programme will be obliged to draw from the recent departure of Robert Hunter from the Department of Energy, where he had been director of energy research. In Congress and elsewhere, those who have been trying for decades to persuade tokamaks to burn deuterium and tritium had been complaining about Hunter's activities: he diverted funds from magnetic to laser fusion research, tried to stall construction of the Compact Ignition Tokamak and, worst of all, refused to take physicists at their word when they assured him the magnetic fusion programme was proceeding as planned towards commercial energy generation.

Hunter was, no doubt, politically a clumsy man. He shifted money from one budget category to another without consulting the appropriate Congressional committees. He further irked Robert Roe, the chairman of the House Committee on Science, Science and Technology, by observing in a departmental memorandum that Princeton was not the automatic choice for the site of a new tokamak because of political concerns over radioactivity; Roe, coming across this note at a fractious hearing, was in no mood to be told by a federal administrator what was or was not a political issue in his home state.

There will be many sighs of relief and little lamentation at Hunter's going. But before the tokamak community congratulates itself too much, they should ponder something: for the first time since the oil crisis of the early seventies, fusion energy was the subject of a noisy political debate. A dozen congressmen grappled intently with plasma quality factors and confinement times. In fighting off Hunter's attack, scientists who had languished under level funding for fifteen years found themselves being praised by some influential voices. With a more timid and less engaging character in Hunter's place, the magnetic fusion programme may well return to the political backwaters. Physicists had better make sure that this does not also mean a return to the financial neglect and sloth of the last decade. 